\title{
Blood group and its correlation with cardiovascular risk factors: A community survey
}

\author{
Opeyemi O. Oni, ${ }^{1}$ Patience O. Akinwusi, ${ }^{2}$ Kehinde Joyce Olufemi-Aworinde, ${ }^{3}$ Abiona $O$. \\ Odeyemi, ${ }^{1}$ Idowu Ajibola, ${ }^{4}$ Oluwaseyi K. Israel, ${ }^{4}$ Gbenga M. Israel, ${ }^{1}$ Oluwabukola Ala, ${ }^{1}$ \\ Joel O. Akande, ${ }^{5}$ Ayodele O. Aremu, ${ }^{4}$ Adewumi Durodola, ${ }^{6}$ James I. Owolabi ${ }^{7}$ \\ ${ }^{1}$ Department of Medicine, Bowen University, Iwo; ${ }^{2}$ Department of Medicine, Osun State University, Osogbo; \\ ${ }^{3}$ Department of Haematology and Blood transfusion, Bowen University, Iwo; ${ }^{4}$ Department of Community \\ Medicine, Bowen University, Iwo; ${ }^{5}$ Department of Chemical Pathology, Bowen University, Iwo; ${ }^{6}$ Department \\ of Family Medicine, Bowen University, Iwo; ${ }^{7}$ Department of Surgery, Bowen University, Iwo, Nigeria
}

\begin{abstract}
Cardiovascular disease is a leading cause of morbidity and mortality globally. Non-O blood groups have been shown to confer a high risk of coronary heart disease. There is paucity of data on the relationship between blood group and left ventricular hypertrophy, among other cardiovascular risk factors. A community-based
\end{abstract}

Correspondence: Opeyemi O. Oni Department of Medicine, Bowen University, PMB 4002 and P.O Box 15, Ogbomoso, Oyo State.

Tel.: $+234(0) 8058435811$.

E-mail: oniopeyemi64@gmail.com

Key words: Blood group; rhesus; left ventricular hypertrophy; triglycerides; pulse pressure; systolic blood pressure.

Acknowledgment: We want to acknowledge the management of the Bowen University Teaching hospital, the Medical Director and staff of Baptist Hospital Ejigbo, and His Royal Highness, The Ogiyan of Ejigbo land. Without their support, this study would not have been actualized.

Conflict of interest: The authors declare no conflict of interest.

Availability of data and materials: All data generated or analyzed during this study are included in this published article.

Ethics approval and consent to participate: The ethical approval was obtained from the Bowen University Teaching Hospital ethical review board NHREC/12/04/2012. A signed letter of confirmed consent was obtained from all subjects participating in the study.

Informed consent: Written informed consent was obtained from legally authorized representatives for anonymized patient information to be published in this article.

Received for publication: 14 October 2021.

Revision received: 26 January 2022.

Accepted for publication: 11 February 2022.

This work is licensed under a Creative Commons Attribution NonCommercial 4.0 License (CC BY-NC 4.0).

${ }^{\circ}$ Copyright: the Author(s), 2022

Licensee PAGEPress, Italy

Annals of Clinical and Biomedical Research 2022; 3:164

doi:10.4081/acbr:2022.164 study was done to evaluate the blood groups and their associations with conventional cardiovascular risk factors in Ejigbo. Anthropometry, blood pressure and other clinical variables were measured. Blood samples were taken for biochemical analysis for blood group typing, serum cholesterol and triglyceride assay. A 12lead electrocardiogram was performed. The analysis was done using SPSS version 20 to determine possible relationships between the variables. Two hundred and six cases were recruited and analyzed. The prevalence of the various groups was as follows: A 23\%; B-31.4\%; AB-4.4\%; O-41.2\%; rhesus-positive-92.7\% and rhesus-negative-7.3\%. Blood group B had similar systolic blood pressure $(136.0 \pm 23.9$ vs $137.3 \pm 22.3 ; \mathrm{p}=0.726)$, higher SokolowLyon voltage sum $(3.3 \pm 1.1$ vs $2.9 \pm 0.9 ; \mathrm{p}=0.025)$ and serum triglycerides [14(21.9\%) vs7(8.4\%), $\mathrm{p}=0.021]$ than those with blood group O. Those with Rhesus Positive status had longer PR interval $(169.3 \pm 25.4$ vs $154.2 \pm 19.1$; p value $=0.055)$ and $\mathrm{QRS}$ duration $(83.8 \pm 12.8$ vs $78.4 \pm 7.6$; p value $=0.043)$ than those with Rhesus negative blood groups. Binary logistic regression revealed blood group B as an independent determinant of left ventricular hypertrophy(LVH) (OR: 3.028; p=0.012; 95\% CI:1.275-7.192). Blood group B is a determinant of LVH. Rhesus positive status is associated with delayed electrical conduction through the myocardium.

\section{Introduction}

Non-O blood groups have been shown to confer a high risk of coronary heart disease , accounting for $6.27 \%$ of all cases. ${ }^{1} \mathrm{~A}$ recent meta-analysis has also supported the earlier findings, showing that blood group A has the strongest predisposition to coronary heart disease (CHD) among the non-O blood groups. ${ }^{2}$ Arterial strokes, peripheral vascular disease and myocardial infarction have all been shown to be increased in the Non-O blood group population. ${ }^{3}$ Another study in the Chinese people showed that the non-O blood group, especially blood groups A and B, were independent predictors of myocardial infarction in those with established CVD. ${ }^{4}$

In the Multi-ethnic study of Atherosclerosis study, the A blood group was found to be associated with an increased prevalence of peripheral arterial disease in African Americans. ${ }^{5}$ Also, a study in Senegal showed that blood group A was associated with a higher prevalence of ischaemic stroke and coronary artery disease. ${ }^{6}$ However, there appears to be no study in indigenous Africans on the relationship between blood group and left ventricular hypertrophy, among other cardiovascular risk factors.

We therefore set out to evaluate the blood groups and their associations with electrocardiographic left ventricular hypertro- 
phy(LVH), alongside other conventional cardiovascular risk factors in Ejigbo.

\section{Materials and Methods}

\section{Study area}

Ejigbo is a rural community in southwest Nigeria. It lies along Latitude 7.54 '0N Longitude $4 \square 18$ '54” E /Latitude 7.90000 Longitude $4.31500 \square \mathrm{E}$. It is about 426 meters above sea level and it receives about $133 \mathrm{~cm}$ depth of rain annually. The population was counted to be 132,515 in 2006 and is made up of traders and farmers, with teachers, commercial drivers and other professions composing the rest of its inhabitants. ${ }^{7}$ The study was conducted at the field adjacent to Baptist Medical Centre, Ejigbo, Osun State. This study was a cross-sectional, descriptive study.

\section{Sample size determination}

Using Leslie Kish formula, a minimum sample size of 185 was estimated for the study. Prevalence of left ventricular hypertrophy $(12.5 \%)$ in a previous study was used. ${ }^{8}$ Tolerable margin of error was set at $5 \%$ and a non-response rate of $10 \%$ was envisaged among the respondents and corrected for.

\section{Study population}

The study population was made up of 206 people in the community. Subjects older than 18 years and who gave informed consent were included into the study. Females who were pregnant were excluded from the study. High blood pressure was defined according to $\mathrm{WHO} / \mathrm{ISH}$ guideline: $\mathrm{A} \mathrm{SBP} \geq 140 \mathrm{mmHg}$ and/or DBP $\geq 90 \mathrm{mmHg}$ or being on treatment. ${ }^{9}$

Blood pressure (BP) was taken using the aneroid sphygmomanometer with appropriate cuff sizes. Blood pressure was taken after allowing at least 5 minutes rest and after ensuring that patients had not taken coffee or smoked cigarette within 30 minutes of taking BP. Systolic BP and DBP were taken as Korotkoff's sound I and V (disappearance) respectively. The BP readings were recorded to the nearest $2 \mathrm{mmHg}$. Three BP readings were taken and the average reading was used for statistical analysis

The ethical approval was obtained from the Bowen University Teaching Hospital ethical review board NHREC/12/04/2012. A signed letter of confirmed consent was obtained from all subjects participating in the study.

\section{Subject assessment}

The study made use of a pretested, semi-structured interviewer-administered questionnaire. The WHO-STEPS questionnaire was adopted and the questionnaire, containing questions on demographic, socioeconomic status and habits of the subjects (sex, age, family status and educational levels, smoking and alcohol use etc) was administered under the supervision of the investigator.

Each participant had his/her weight $(\mathrm{kg})$ measured using a standard hospital weighing scale with a weight limit of $120 \mathrm{Kg}$ and error margin of $0.4 \pm 0.3 \mathrm{~kg}$. The privacy of subjects was upheld during all measurements. Each subject was in minimal clothing with shoes off while being weighed. Height (m) was measured against a graduated height scale with patients in erect position and unshod.

Body mass index (BMI) was calculated from the weight and height as follows:

BMI $=$ weight $(\mathrm{kg}) / \operatorname{Height}^{2}\left(\mathrm{~m}^{2}\right)$.
Blood sample collection, storage and laboratory analysis

Venous blood was collected in plain universal and lithium heparin bottles and centrifuged at 3,000xg for 5 minutes. The plasma obtained was stored frozen at $-20^{\circ} \mathrm{C}$ before analysis. Plasma from each participant was analyzed in batches using standards and controls for all the biochemical parameters. Blood group determination was done using standard methods.

The enzymatic endpoint was used for lipid profile (Total Cholesterol, HDL-Cholesterol and Triglycerides) parameters except LDL-Cholesterol. Low-density lipoprotein cholesterol was calculated using Friedewald formula. ${ }^{10}$ Dyslipidaemia classification for the cut off points are derived from the American Heart Association as follows: Total cholesterol $>5.2 \mathrm{mmol} / \mathrm{L}$, Triglycerides $>1.7 \mathrm{mmol} / \mathrm{L}$, Low-density lipoprotein $>3.4 \mathrm{mmol} / \mathrm{L}$, and High-density lipoprotein $<0.9 \mathrm{mmol} / \mathrm{L} .{ }^{11}$ The definition of dyslipidaemia used in this study is an abnormality in at least one of the above domains.

\section{Electrocardiogram}

Electrocardiography (ECG) - 12 lead resting ECG was done on all the subjects (using Nihon Kohden cardiofax Q-9130K and Cardimax FX-3101 devices). Left ventricular hypertrophy was defined using standard criteria. ${ }^{12-16}$ Other ECG variables were assessed using standard protocol. Interpretation was done by an experienced cardiologist.

\section{Data management and analysis}

All data obtained were entered into a standard proforma. Continuous variables were expressed as mean \pm Standard Deviation [SD] while categorical variables were expressed as count (percentages). Data analysis was done using IBM SPSS Statistics for Windows, Version 20.0.

The Shapiro-Wilks test was used to assess for normality of distribution of variables. The means of continuous variables was compared using the Student's $t$-test for independent groups. For categorical variables, Chi-square and/or Fisher's exact test was applied to test the equality of distributions between the two groups. The demographic, anthropometric, laboratory and electrocardiographic characteristics of subjects were evaluated first, among the four $\mathrm{ABO}$ blood groups and between the two rhesus groups, using ANOVA and independent t-test respectively. Variables with significant relationships were entered into a model to evaluate for determinants of LVH. A two-tailed p-value of less than or equal to 0.05 was said to be significant.

\section{Results}

Two hundred and six cases were recruited and analyzed. The prevalence of the various $\mathrm{ABO}$ groups was as follows: A - $23 \%$; B$31.4 \%$; AB- $4.4 \%$ and $\mathrm{O}-41.2 \%$. The prevalence of the Rhesus groups was as follows: rhesus-positive- $92.7 \%$ and rhesus-negative- $7.3 \%$.

\section{LVH and blood groups}

Major electrocardiographic LVH criteria were utilized in the analysis- most did not show significant differences among the groups. Only those that were significant (or showed a trend towards significance) were included in the table. The SokolowLyon criteria was the only one that showed a difference, with blood groups B and A showing prevalence values of $42 \%$ and $27 \%$ for 
LVH (Sokolow-Lyon) respectively. None of the subjects with blood group AB had LVH (0\%).

The Estee point score $\geq 4$ in males showed that those with blood group $\mathrm{O}$ had a tendency towards having LVH. Only 60 people had ever consumed alcohol in the entire cohort of patients. Among these, only 20 of them consumed alcohol within the last 12 months- $4(\mathrm{~A}), 8(\mathrm{~B}), 0(\mathrm{AB})$ and $5(\mathrm{O})\left(\mathrm{p}=0.777^{\mathrm{F}}\right)$; out of which only 14 drank alcohol in the previous 30 days: $1(\mathrm{~A}), 5(\mathrm{~B}), 0(\mathrm{AB})$ and 5(O). Nine people also smoked cigarettes currently: 3(A), 1(B),
$1(\mathrm{AB})$ and $4(\mathrm{O})$. Details are seen in Table 1.

Higher serum triglycerides were found in the non-O as compared to the O group $[1.14 \pm 0.88$ vs $0.91 \pm 0.65 ; \mathrm{p}=0.042]$. Also, the P-wave amplitude in V1 [0.02 \pm 0.03 vs $0.008 \pm 0.02 ; \mathrm{p}=0.018]$ and lead II $[0.073 \pm 0.16$ vs $0.033 \pm 0.07$; $=0.073]$ were higher in the non-O than the $\mathrm{O}$ group, suggesting larger right atria in the former. There was also a tendency towards having left ventricular hypertrophy in those in the non-O group, largely due to significantly deeper S waves in V1. Details are seen in Table 2.

Table 1. Showing the distribution of various variables within the $\mathrm{ABO}$ blood group system.

\begin{tabular}{|c|c|c|c|c|c|}
\hline Variables & $\begin{array}{c}\text { Blood Group A, } \\
n=44(\%)\end{array}$ & $\begin{array}{c}\text { Blood Group AB, } \\
n=9(\%)\end{array}$ & $\begin{array}{c}\text { Blood Group B, } \\
n=62(\%)\end{array}$ & $\begin{array}{c}\text { Blood Group 0, } \\
\mathrm{n}=80(\%)\end{array}$ & P-value \\
\hline $\begin{array}{l}\text { Sex } \\
\text { Male } \\
\text { Female }\end{array}$ & $\begin{array}{l}18 \\
26\end{array}$ & $\begin{array}{l}2 \\
7\end{array}$ & $\begin{array}{l}15 \\
47\end{array}$ & $\begin{array}{l}17 \\
63\end{array}$ & 0.163 \\
\hline Elevated Triglycerides & $5(11.1)$ & $3(33.3)$ & $14(21.9)$ & $7(8.4)$ & 0.054 \\
\hline Elevated LDL & $22(48.9)$ & $5(55.6)$ & $22(34.4)$ & $27(32.5)$ & 0.233 \\
\hline Low HDL & $12(26.7)$ & $2(22.2)$ & $6(9.4)$ & $12(14.5)$ & $0.045^{*}$ \\
\hline Hypertension & $23(60.5)$ & $5(55.6)$ & $32(56.1)$ & $54(72)$ & 0.163 \\
\hline Ever consumed alcohol & $20(47.6)$ & $2(22.2)$ & $13(57)$ & $17(22)$ & $0.017^{*}$ \\
\hline Vigorous intensity work for 10 minutes & $9(23.7)$ & $0(0)$ & $13(22.4)$ & $13(17.6)$ & $0.025^{*}$ \\
\hline Moderate intensity Work for 10 minutes & $10(27)$ & $2(22.2)$ & $20(35.7)$ & $19(25.7)$ & $0.019 *$ \\
\hline Sokolow Lyon V1+V5 & $10(27)$ & $0(0)$ & $21(42)$ & 11(19.3) & $0.017 *$ \\
\hline Cornell Male $(\mathrm{n}=57)$ & $4(23.5)$ & $2(100)$ & $0(0)$ & $0(0)$ & $0.000^{*}$ \\
\hline Cornell Volt Product (Male) & $3(21.4)$ & $1(50)$ & $0(0)$ & $0(0)$ & $0.023^{*}$ \\
\hline Perugia (Male) & $7(41.2)$ & $2(100)$ & $1(7.7)$ & $4(28.6)$ & $0.037^{*}$ \\
\hline Estee Point score $\geq 4$ (Males) & $5(29.4)$ & $1(50)$ & $2(14.3)$ & $9(64.3)$ & 0.058 \\
\hline
\end{tabular}

$\mathrm{X}^{2}$ of Sokolow Lyon VIV5:12.443; *: P-value $\leq 0.05$.

Tables 2. Shows the clinical, electrocardiographic and laboratory variables between those with Blood groups $\mathrm{O} v \boldsymbol{s}$ non-O.

\begin{tabular}{|c|c|c|c|c|}
\hline Variables & 0 vs $N o n-0 n / n$ & 0 group (\%) & Non-0 group (\%) & P-value \\
\hline Age (years) & $80 / 165$ & $59.9 \pm 15.8$ & $57.8 \pm 16.5$ & 0.354 \\
\hline $\begin{array}{l}\text { Sex } \\
\text { Male } \\
\text { Female }\end{array}$ & $80 / 167$ & $\begin{array}{l}17 \\
63\end{array}$ & $\begin{array}{c}46 \\
121\end{array}$ & 0.288 \\
\hline Serum Triglycerides & $83 / 133$ & $0.9 \pm 0.7$ & $1.1 \pm 0.9$ & $0.042^{*}$ \\
\hline Elevated Triglycerides & $83 / 133$ & $7(8.4)$ & $25(18.8)$ & $0.037^{*}$ \\
\hline Hypertension & $75 / 142$ & $54(72)$ & $89(62.7)$ & 0.168 \\
\hline Sokolow-Lyon-Rappaport (V2+V6) & $57 / 139$ & $4(7)$ & $21(15.1)$ & 0.159 \\
\hline Normal body weight category & $77 / 149$ & $21(27.3)$ & $54(36.2)$ & 0.184 \\
\hline Maximum attained education & $74 / 144$ & & & \\
\hline Primary education( $\leq$ 6yrs in school) & & $43(58.1)$ & $64(44.4)$ & 0.056 \\
\hline Secondary education ( $\leq 12 y r s$ in school) & & $63(85.1)$ & $88(61.1)$ & $0.000^{*}$ \\
\hline P amplitude in lead II & $54 / 136$ & $0.03 \pm 0.1$ & $0.07 \pm 0.2$ & 0.073 \\
\hline P wave (initial force) in V1 & $51 / 136$ & $0.01 \pm 0.02$ & $0.02 \pm 0.03$ & $0.018^{*}$ \\
\hline Paxis & $55 / 129$ & $58.5 \pm 25.5$ & $49.2 \pm 32$ & 0.058 \\
\hline $\mathrm{SV}_{1}$ & $56 / 142$ & $1.04 \pm 0.59$ & $1.22 \pm 0.56$ & $0.045^{*}$ \\
\hline $\mathrm{SV}_{1} \mathrm{RV}_{6}$ & $57 / 141$ & $2.31 \pm 0.88$ & $2.55 \pm 0.89$ & 0.082 \\
\hline $\mathrm{R}$ in lead I & $56 / 137$ & $0.8 \pm \pm 0.4$ & $0.9 \pm 0.4$ & $0.014^{*}$ \\
\hline $\mathrm{T}$ axis & $53 / 133$ & $52.3 \pm 42.8$ & $40.3 \pm 25.1$ & $0.019 *$ \\
\hline
\end{tabular}

*: P-value $\leq 0.05$. 
Those with blood group $\mathrm{O}$ had lower serum triglycerides and lower voltage sums for LVH as compared to those with blood group B. This was in spite of the fact that those who were diagnosed with hypertension were commoner in the blood group O. See Figures 1 and 2.

Those with blood group A have taller voltage sums (Sokolow Lyon and Gubner-Ungerleider) for LVH, longer PR intervals and a tendency to have wider pulse pressures than those with blood group AB. See Figure 3.

The subgroup study of electrocardiographic LVH among the ABO blood groups using the Bonferroni adjustments in ANOVA showed that the Sokolow-Lyon voltage sum was significantly different specifically between blood groups $\mathrm{B}$ and $\mathrm{AB}$. Therefore, a Ttest was done to evaluate the same variables between blood groups $\mathrm{B}$ and $\mathrm{AB}$. In addition to having higher Sokolow-Lyon LVH voltages, the systolic blood pressure and pulse pressure were also higher in those with B group while diastolic blood pressure was not. However, the heart rate of those with the $\mathrm{AB}$ group was higher.

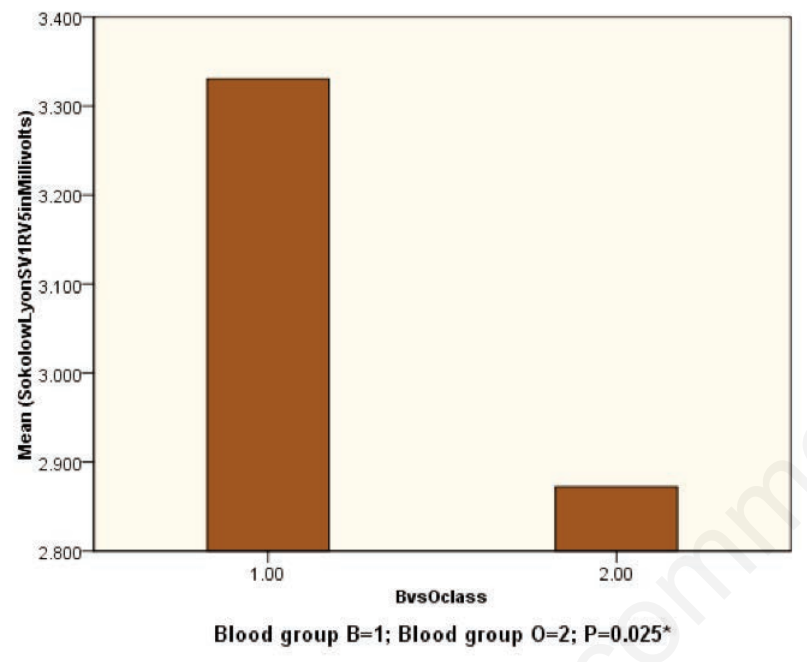

Figure 1. Showing left ventricular hypertrophy between those with blood groups $\mathrm{B}$ and $\mathrm{O}$. *:P $\leq \mathbf{0 . 0 5}$.

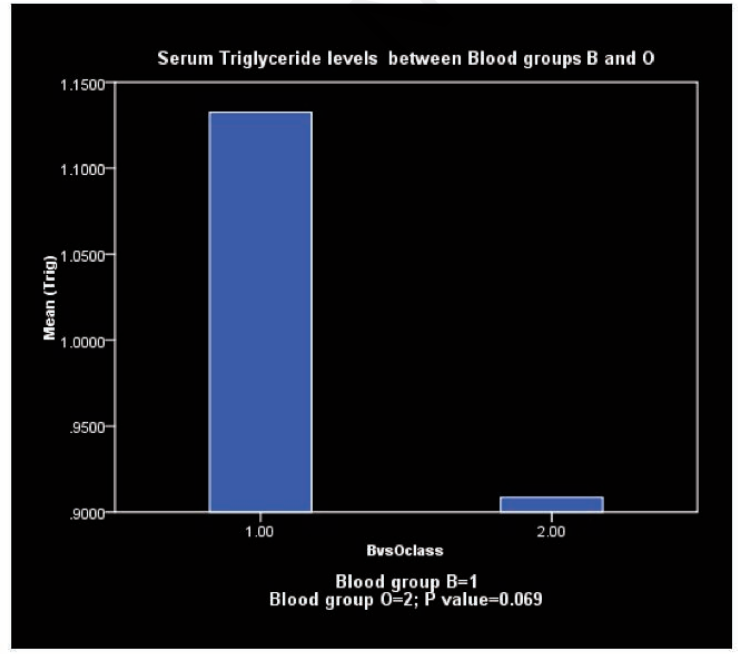

Figure 2. Shows the mean Triglyceride levels between blood groups $B$ and $O$.
Also, LDL-C values and total cholesterol-HDL ratios were higher in those with $\mathrm{AB}$ than those with B. See Figure 4.

Those who were rhesus positive had greater incidence of left atrial enlargement, longer PR interval and QRS duration than those who were rhesus negative. The waist and hip circumferences showed a trend towards being higher in those with a rhesus positive status. However, the Rhesus negative group had higher LDL cholesterol levels. Details are seen in Table 3.

Subjects with blood group $\mathrm{AB}$ had lower blood pressures $[121.7 \pm 13.9$ vs $137.3 \pm 22.3 ; \mathrm{p}=0.043]$, better pulse pressures [43.9 \pm 10.3 vs $56 \pm 15.1 ; \mathrm{p}=0.022]$, a tendency towards having less sum of RV5+SV1, (criterion used for LVH) but paradoxically worse dyslipidaemia (all AB subjects had dyslipidaemia in one domain or the other) than those with blood group $\mathrm{O}[9(100 \%) v s$ $45(54.2 \%) ; \mathrm{p}=0.009]$. Those with blood group $\mathrm{AB}$ also had a tendency to complain of chest pain more than those with blood group O [5(55.6\%) vs 20(26.3\%); $\mathrm{p}=0.116]$. There also seemed to be an inverse relationship between education and hypertension- those

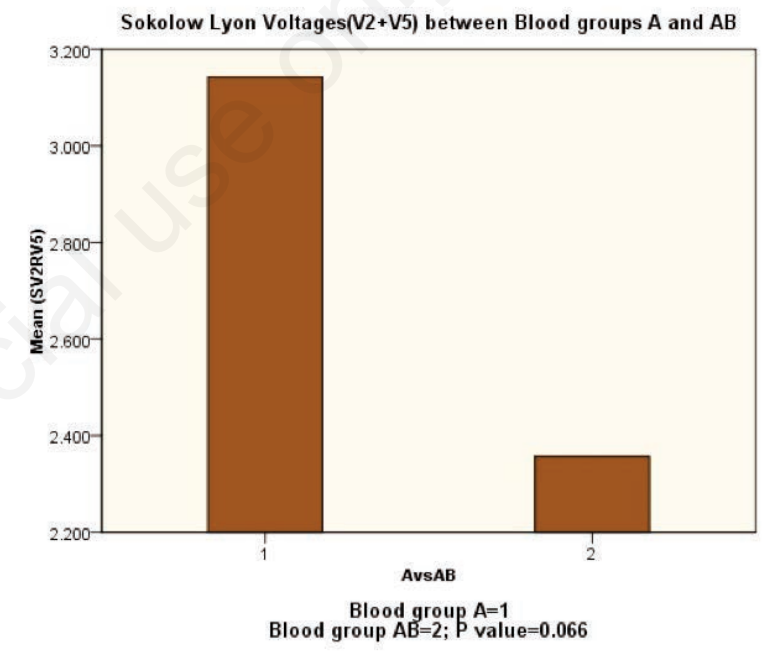

Figure 3. Shows the mean voltages for left ventricular hypertrophy (Sokolow-Lyon-Rappaport) between blood groups A and AB.

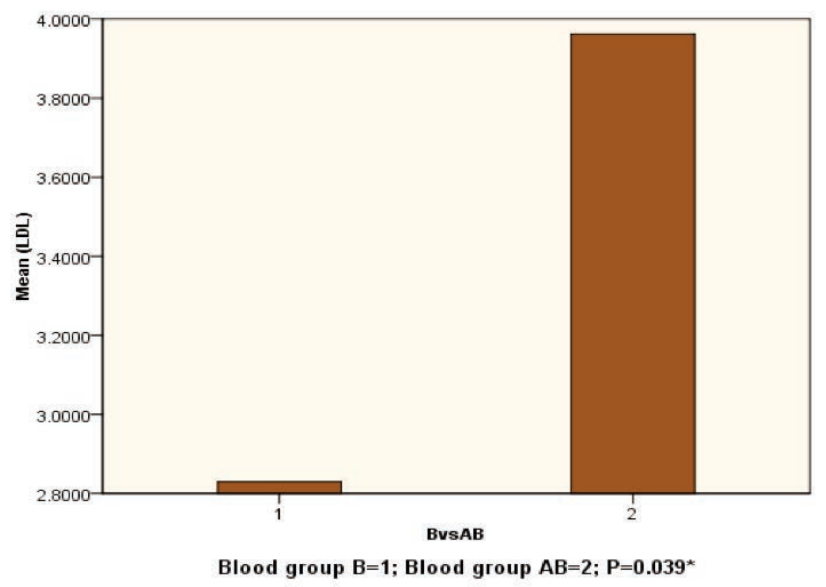

Figure 4. Shows the mean low-density lipoprotein (LDL) levels between blood groups $\mathrm{B}$ and $\mathrm{AB} *: \mathrm{P} \leq \mathbf{0 . 0 5}$. 
who were more educated (blood group $\mathrm{AB}$ ) were less hypertensive [5(55.6\%) vs 63(85.1\%); $\mathrm{p}=0.052]$.

When binary logistic regression was done to assess for the blood group determinants of LVH, only blood group B was an independent determinant of $\mathrm{LVH}$, accounting for between 8.0 and $11.5 \%$ of the LVH seen among the study subjects. See Table 4.

\section{Discussion}

In this study, in the ABO blood group, those with non-O blood groups had less secondary education $88(61.1 \%)$ vs $63(85.1 \%) \mathrm{p}=0.000$, had higher serum triglyceride levels $[1.14 \pm 0.88$ vs $0.91 \pm 0.65 ; \mathrm{p}=0.042]$, taller $\mathrm{P}$ wave amplitudes (in leads V1) $0.02 \pm 0.03$ vs $0.008 \pm 0.02$; $\mathrm{p}=0.018$ and a tendency to having higher electrocardiographic 'left ventricular hypertrophy' voltages than those with $\mathrm{O}$ blood group $[2.55 \pm 0.89$ vs $2.31 \pm 0.88$; $\mathrm{p}=0.082]$. Elevated serum triglyceride levels has been shown to increase the odds of developing $\mathrm{LVH}$ in the general populace. ${ }^{17}$
Those with blood group B had significantly higher incidence of $\mathrm{LVH}$, with 3-fold the odds of developing LVH than those with blood group $\mathrm{O}$. This was in spite of the fact that those with $\mathrm{O}$ blood group had a tendency to be more hypertensive, though the measured blood pressure values were essentially same.

The $\mathrm{N}$-acetylgalactoseamine and D-galactose side chains that define the A and B blood groups respectively interact with von Willebrand factor to promote platelet aggregation and thrombus formation. ${ }^{18}$ These antigenic determinants interact with endothelium-derived adhesion molecules to cause cardiovascular diseases. ${ }^{19}$ Interestingly, the ABO 'blood group' antigens are not specific to blood cells, but are found in salivary glands, respiratory epithelium and the gastrointestinal epithelium and have been found to be determinants of non-cardiovascular diseases and malignancies. ${ }^{20}$ These blood group antigens have been shown to exhibit wide functional diversity, being involved with transcellular transport, serving as structural proteins, enzymes and adhesion molecules, among others. ${ }^{21}$

In post-menopausal women and hypertensive adults with cere-

Table 3. Showing the clinical, laboratory and electrocardiographic parameters between those with Rhesus positive and Rhesus Negative blood groups.

\begin{tabular}{|c|c|c|c|c|}
\hline Variables & Rhesus neg/positive $n / n$ & Rhesus Negative & Rhesus Positive & P-value \\
\hline $\begin{array}{l}\text { Sex } \\
\quad \text { Male } \\
\text { Female }\end{array}$ & $15 / 182$ & $\begin{array}{l}6 \\
9\end{array}$ & $\begin{array}{c}46 \\
136\end{array}$ & 0.214 \\
\hline $\begin{array}{l}\text { Moderate intense work for } 10 \mathrm{~min} \\
\text { Yes } \\
\text { No }\end{array}$ & $13 / 165$ & $\begin{array}{c}1 \\
12\end{array}$ & $\begin{array}{c}52 \\
113\end{array}$ & 0.112 \\
\hline $\begin{array}{l}\text { Occupation } \\
\text { Government employee } \\
\text { Non-Government employee } \\
\text { Self employed } \\
\text { Student } \\
\text { Home maker } \\
\text { Retired } \\
\text { Unemployed-able to work } \\
\text { Unemployed-unable to work }\end{array}$ & $15 / 178$ & $\begin{array}{c}0 \\
0 \\
13 \\
1 \\
0 \\
0 \\
0 \\
1\end{array}$ & $\begin{array}{c}14 \\
14 \\
94 \\
4 \\
1 \\
41 \\
7 \\
3\end{array}$ & 0.054 \\
\hline $\begin{array}{l}\text { Left atrial enlargement } \\
\text { Yes } \\
\text { No }\end{array}$ & $10 / 128$ & $\begin{array}{l}2 \\
8\end{array}$ & $\begin{array}{l}68 \\
60\end{array}$ & 0.053 \\
\hline $\begin{array}{l}\text { Abnormal LDL class } \\
\text { Yes } \\
\text { No }\end{array}$ & $15 / 188$ & $\begin{array}{l}9 \\
6\end{array}$ & $\begin{array}{c}68 \\
120\end{array}$ & 0.067 \\
\hline Total cholesterol (mmol/L) & $15 / 188$ & $5.9 \pm 2.6$ & $5.2 \pm 1.7$ & 0.127 \\
\hline Low density lipoprotein $(\mathrm{mmol} / \mathrm{L})$ & $15 / 188$ & $3.8 \pm 1.9$ & $3.0 \pm 1.5$ & 0.059 \\
\hline PR interval (msec) & $11 / 140$ & $154.2 \pm 19.1$ & $169.3 \pm 25.4$ & 0.055 \\
\hline QRS duration ${ }^{\#}$ (msec) & $12 / 140$ & $78.4 \pm 7.6$ & $83.8 \pm 12.8$ & $0.043^{*}$ \\
\hline Waist circumference (cm) & $14 / 171$ & $83.9 \pm 12$ & $89.4 \pm 12.3$ & 0.110 \\
\hline Hip circumference (cm) & $14 / 170$ & $94.7 \pm 11.1$ & $100.9 \pm 11.9$ & 0.064 \\
\hline Body Surface area $\left(\mathrm{m}^{2}\right)$ & $15 / 169$ & $1.6 \pm 0.2$ & $1.7 \pm 0.2$ & 0.148 \\
\hline
\end{tabular}

${ }^{*}$ Not normally distributed; *: P-value $\leq 0.05$.

Table 4. Binary Logistic regression showing the impact of blood group on electrocardiographic LVH(V1+V5) using blood group O as reference.

\begin{tabular}{lccc} 
Variables & Odds ratio & P value & Confidence Interval \\
Blood group A & 1.549 & 0.381 & $0.582-4.124$ \\
Blood group B & 3.028 & $0.012^{*}$ & $1.275-7.192$ \\
\hline Blood group AB & 0.000 & 0.999 & 0.000 \\
\hline
\end{tabular}

*: P-value $\leq$ 0.05; R2: Cox and Snell-0.080; Nagelkerke: 0.115 . 
brovascular and cardiovascular disease, the A blood group was found by Wiggins et al. ${ }^{22}$ to confer increased odds of having ventricular tachycardia (OR:1.79; CI: 1.41-2.26) and myocardial infarction (OR:1.23; CI:1.05-1.44, as compared to O) while the B blood group had higher odds of both ventricular tachycardia (OR:1.82; CI:1.29-2.57) and ischaemic stroke (OR:1.59; CI:1.172.17). ${ }^{22}$ However, their study was among those with established CVD, not a general population-based research. Also, in those with familial hypercholesterolaemia, patients with the non-O blood group had $>2$-fold prevalence of cardiovascular disease as compared to the blood group $\mathrm{O}$ patients. ${ }^{23}$ The non-O blood group has also been found to have higher odds of having non-alcoholic fatty liver disease, especially blood groups $\mathrm{A}$ and $\mathrm{B} .{ }^{24}$

The mean pulse pressure of those with the $\mathrm{AB}$ groups in this study was less than those with blood group $\mathrm{O}$, with associated reduced electrocardiographic LVH. Increased pulse pressure has been found to be a risk factor for myocardial infarction, increased LV mass and to be predictive of increased cardiovascular mortality. 25,26

One would think that the presence of both antigenic epitopes on the blood cells in the AB population would confer a higher cardiovascular risk profile on them but that seems not to be the case. Instead, there seem to be a dousing effect when both are present, reducing the cardiovascular risk as compared to those with either A or B blood groups. This is in agreement with the findings of Biswas et al. ${ }^{27}$ Most available literature implicates either blood groups $\mathrm{A}$ or $\mathrm{B}$ as the main culprit in different population groups. ${ }^{2,28,29}$ Interestingly, the total cholesterol and LDL-cholesterol in this study were higher in the $\mathrm{AB}$ populace than those with blood group B while the systolic blood pressure and left ventricular hypertrophy indices were higher in the latter.

Those who were rhesus positive had more left atrial enlargement, longer PR interval and QRS duration than those who were rhesus negative (it seems that the rhesus antigen delays the conduction of action potentials across the entire myocardium). The waist and hip circumferences showed a trend towards being more in those with a rhesus positive status. However, the Rhesus negative group had higher LDL cholesterol levels.

\section{Conclusions}

The Non-O blood groups, especially blood group B had higher blood pressure values, left ventricular hypertrophy and serum triglycerides than those with blood group $\mathrm{O}$. The $\mathrm{AB}$ populace tend to have higher total cholesterol and LDL cholesterol than blood group B (which seems to have the highest cardiovascular risk profile due to $\mathrm{LVH}$ ). These suggest that the various $\mathrm{ABO}$ blood group types have their peculiarities and requesting for blood group with a view to assessing cardiovascular risk should be given a strong consideration.

Rhesus positive status was associated with delayed electrical conduction through the myocardium, especially from the atrioventricular node to the ventricular cells. This may necessitate an adjustment of the normal PR and QRS durations based the Rhesus status of people in the general populace.

\section{References}

1. He M, Wolpin B, Rexrode K, Manson JE, Rimm E, Hu FB, et al. ABO blood group and risk of coronary heart disease in two prospective cohort studies. Arterioscler Thromb Vasc Biol
2012;32:2314-20.

2. Chen Z, Yang SH, Xu H, Li JJ. ABO blood group system and the coronary artery disease: An updated systematic review and meta-analysis. Sci Rep 2016;6:23250.

3. Wu O, Bayoumi N, Vickers MA, Clark P. ABO $(\mathrm{H})$ blood groups and vascular disease: A systematic review and metaanalysis. J Thrombosis Haemostasis 2008;6:62-9.

4. Xiaoying H, Qiao S, Hong Q, et al. [Association between ABO blood group and acute myocardial infarction]. Zhonghua Xin Xue Guan Bing Za Zhi 2015;43:785-7.

5. Pike MM, Larson NB, Wassel CL, et al. ABO blood group is associated with peripheral arterial disease in African Americans: The Multi-Ethnic Study of Atherosclerosis (MESA). Thromb Res 2017;153:1-6.

6. BA DM, Sow MS, Diack A, Dia K, Mboup MC, Fall PD, et al. Cardiovascular disease and $\mathrm{ABO}$ blood-groups in Africans. Are blood-group A individuals at higher risk of ischemic disease? A pilot study. Egypt Hear J 2017;69:229-34.

7. City Population. Ejigbo (Local Government Area, Nigeria) Population Statistics, Charts, Map and Location. 2016. Accessed: Dec 14th,2021. Available from: https://www.citypopulation.de/php/nigeria-admin.php?adm2id=NGA030010

8. Akinwusi OP, Asekun-Ola EO, Adebimpe WO, et al. Cardiovascular risk factors and electrocardiographic pattern in two rural communities of Osun State in South West Nigeria. Curr Res Cardiol 2017;4:15.

9. Chobanian AV. The seventh report of the joint national committee on prevention, detection, evaluation, and treatment of high blood pressure. JAMA 2003;289:2560.

10. Friedewald WT, Levy RI, Fredrickson DS. Estimation of the concentration of low-density lipoprotein cholesterol in plasma, without use of the preparative ultracentrifuge. Clin Chem 1972;18:499-502.

11. Kavey R-E, Daniels SR, Lauer RM, et al. American Heart Association Guidelines for Primary Prevention of Atherosclerotic Cardiovascular Disease Beginning in Childhood. Circulation 2003;107:1562-6.

12. Sokolow M, Lyon TP. The ventricular complex in left ventricular hypertrophy as obtained by unipolar precordial and limb leads. Am Heart J 1949;37:161-86.

13. Casale PN, Devereux RB, Alonso DR, et al. Improved sex-specific criteria of left ventricular hypertrophy for clinical and computer interpretation of electrocardiograms: validation with autopsy findings. Circulation 1987;75:565-72.

14. Verdecchia P, Schillaci G, Borgioni C, et al. Prognostic value of a new electrocardiographic method for diagnosis of left ventricular hypertrophy in essential hypertension. J Am Coll Cardiol 1998;31:383-90.

15. Gubner R, Ungerleider HE. Electrocardiographic criteria of left ventricular hypertrophy: factors determining the evolution of the electrocardiographic patterns in hypertrophy and bundle branch block. Arch Intern Med 1943;72:196-209.

16. Romhilt DW, Estes EH. A point-score system for the ECG diagnosis of left ventricular hypertrophy. Am Heart J 1968;75:752-8.

17. Sundström J, Lind L, Vessby B, et al. Dyslipidemia and an unfavorable fatty acid profile predict left ventricular hypertrophy 20 years later. Circulation 2001;103:836-41.

18. Franchini M, Lippi G. The intriguing relationship between the $\mathrm{ABO}$ blood group, cardiovascular disease, and cancer. BMC Medicine 2015;13:7.

19. Zhang H, Mooney CJ, Reilly MP. ABO Blood Groups and Cardiovascular Diseases. Int J Vasc Med 2012;2012:11. 
20. Gilmiyarova FN, Kolotyeva NA, Kuzmicheva VI, et al. Blood Group and Human Diseases (Review Of Literature). Russ Clin Lab Diagnostics 2020;65:216-21.

21. Cartron JP, Colin Y. Structural and functional diversity of blood group antigens. Transfus Clin Biol 2001;8:163-99.

22. Wiggins KL, Smith NL, Glazer NL, et al. ABO genotype and risk of thrombotic events and hemorrhagic stroke. J Thromb Haemost 2009; 7:263-9.

23. Paquette M, Dufour R, Baass A. ABO blood group is a cardiovascular risk factor in patients with familial hypercholesterolemia. J Clin Lipidol 2018;12:383-389.e1.

24. Zhong GC, Liu S, Wu YL, et al. ABO blood group and risk of newly diagnosed nonalcoholic fatty liver disease: A case-control study in Han Chinese population. PLoS One 2019;14:e0225792.

25. Palmieri V, Devereux R, Hollywood J, et al. Association of pulse pressure with cardiovascular outcome is independent of left ventricular hypertrophy and systolic dysfunction: the strong heart study. Am J Hypertens 2006;19:601-7.

26. Madhavan S, Ooi WL, Cohen H, Alderman MH. Relation of pulse pressure and blood pressure reduction to the incidence of myocardial infarction. Hypertension 1994;23:395-401.

27. Biswas S, Ghoshal PK, Halder B, Mandal N. Distribution of $\mathrm{ABO}$ blood group and major cardiovascular risk factors with coronary heart disease. Biomed Res Int 2013;2013:782941.

28. Wazirali H, Ashfaque RA, Herzig JW. Association of blood group A with increased risk of coronary heart disease in the Pakistani population. Pak J Physiol 2005;1:1-2.

29. Lee HF, Lin YC, Lin CP, et al. Association of blood group A with coronary artery disease in young adults in Taiwan. Intern Med 2012;51:1815-20. 